\title{
CAREER CONSULTATION AS AN INTERVENTION STRATEGY IN ALLEVIATING FAMILY'S MENTAL HEALTH: A CASE STUDY ON STUDENTS WITH DISABILITIES
}

\author{
Norhayati Mohd Noor ${ }^{*}$, Maslawati Mohamed ${ }^{1}$, Azmawaty Mohamad Nor ${ }^{2}$ \\ and Rohaya Abdullah ${ }^{3}$ \\ ${ }^{1}$ Faculty of Education, Universiti Kebangsaan Malaysia, 43600 UKM Bangi, \\ Selangor, Malaysia \\ ${ }^{2}$ Department of Education Psychology and Counseling, Faculty of Education, \\ Universiti Malaya, 50603 Kuala Lumpur, Malaysia \\ ${ }^{3}$ School of Educational Studies, Universiti Sains Malaysia, \\ 11800 USM Pulau Pinang, Malaysia \\ *Corresponding author: norhayati@ukm.edu.my
}

Publication date: 31 March 2019

To cite this article: Norhayati Mohd Noor, Maslawati Mohamed, Azmawaty Mohamad Nor, \& Rohaya Abdullah. (2018). Career consultation as an intervention strategy in alleviating family's mental health: A case study on students with disabilities. Asia Pacific Journal of Educators and Education, 33, 47-55. https://doi.org/10.21315/apjee2018.33.4

To link to this article: https://doi.org/10.21315/apjee2018.33.4

\begin{abstract}
Relevant information is critical in assisting families and teachers to help students with disabilities in planning their careers appropriate for their capabilities and abilities. Having the correct information and understanding will alleviate the psychological burden faced by family members in dealing with children with special educational needs. This study aimed to explore the knowledge and understanding of parents with special needs on the job marketability of their children. This qualitative study was conducted with 11 multi-case multi-site families of special education students. The consultation process for phase one involved consultations conducted by special education teacher trainees. The second phase of consultation and collaborative process involved students and special education students with undergraduate education guidance and counselling. The verbatim data were analysed using NVivo 11. The study showed that families still lack knowledge in the marketability of their special needs children particularly due to the limited information channel. The findings showed that knowledge on job marketability can help the parents plan their special
\end{abstract}


needs children's job marketability, which in turn, would directly contribute to the family wellbeing.

Keyword: family, family consultation, marketability work skill, children with special needs.

\section{INTRODUCTION}

Consultation is an activity offered in various work setting, which is a professional supportive relationship process with individuals or group. Consultation is defined as problem solving process that is done collaboratively between two or more consultants and consultations in the efforts to benefit an individual or clients in carrying out responsibilities in a two-way interaction (Hammack, 1994). Consultation in schools helps teachers to implement social and emotional learning programmes to students (a) by having a caring relationship that form the foundation for a lasting learning, (b) with emotions which affect how learning takes place and what is learned, and (c) with goal setting and problem solving which provide direction and energy for learning (Akin-Little, Little, \& Delligatti, 2004; Duckett, Kagan, \& Sixsmith, 2010). Currently, consultation is expanding in schools focusing on increasing students' achievements in academic, discipline, social, psychology and skills. According to Coyne (2006), consultation with children and their parents at schools is becoming a major point to be considered which has been actively acknowledged and promoted by non-governmental organisation (NGOs) in the West. Perera-Diltz, Moe and Mason (2011) found out that 79\% of consultations that were carried out by counsellors also involved the principal, parents and teachers. Her study also suggested that the consultation in schools can adopt the consultation of interdisciplinary model. It means that the consultations in schools do not only involve normal students, but also for students with disabilities or also known as students with special educational needs.

Consultation with students of special educational needs can help to tighten the bond between parents and the school system (Hoskins, Astramovich, \& Smith, 2007). Hoskins writes that various models of consultations should be practiced by the counsellors and teachers so that the consultations are beneficial for all the students in schools including students with special educational needs. These special students should be given the power to act as agents of change in their own lives. They will decide what they want to be by being actively involved in making decisions, whether they want to go to school or go to work and care for their own lives within their community. Parents, educators and other professionals are central to the support system for these students especially in developing skills for these students while they are at primary or secondary schools and even at 
institutions of higher learning (Izzo \& Lamb, 2003). According to Aizan Sofia, Jamiah and Noremy (2016), family roles are important in providing psychological and psychosocial support of special education children.

Job marketability is defined as work opportunities or individuals' capability to get a job. There are many studies on job marketability conducted in Malaysia but the focus is on normal students rather than students of special educational needs. According to Lau, Ahmad and Chew (2011) job offers for these special students are very limited in the government and private sectors. Although there are employment policies for these special students in the government sector, such opportunities are very limited compared to the number of jobs with the actual figure of disabled people in Malaysia. Therefore, these researchers suggested that close kin of these special students such as parents and family members should participate in the career counselling process. Thus, the consultation of job marketability involving special education teacher trainees as consultants, the parents or family members as consultees can help these special students (the clients) to function effectively in job marketability skills. They will realise the various alternatives offered in the job market and they will increase their potentials in job marketability for future plan.

\section{PROBLEM STATEMENT}

Job opportunities among disabled individuals are still low in Malaysia (Ministry of Women, Family and Community Development, 2006). Several studies and surveys carried out in universities and related government agencies showed that many factors and obstacles were faced by people with disabilities in getting a job, although they have similar academic qualifications as normal people (Lau et al., 2011). A study carried out by the Ministry of Women, Family and Community Development (2006) highlights 11 findings that show people with disabilities really need to be given more exposure and awareness in job marketability that covers training, skills, workshops and employers' acceptance. In the study, 90.8\% of family members of people with disabilities thought that more trainings and services were needed in order to improve the lives of disabled people in terms of training, job preparation, daily care and recreation. Moreover, the study showed that family members also need support in terms of training, workshop, counselling and moral support.

Studies on the level of awareness towards issues related to people with disabilities such as issues of adults with intellect deficiency were carried out by the Ministry of Women, Family and Community Development (2006). This study was conducted with the aim to observe five objectives. 
1. To understand and assess the situation for people with disabilities with intellectual challenges.

2. To identify the services that they need.

3. To identify the support that the families need.

4. To know the work situation for them.

5. To know the needs and attitude of the employers.

The study shows that people with disabilities lacked awareness of the working world that demands adaptation to the social surrounding. A study done by Zainudin, Norani and Ramlee (2009) suggests two skills for students of special educational needs with learning disabilities. They should learn internal vocational skills like craft, agriculture, entrepreneurship and cooking as well as vocational skills like sewing, carpentry, fixing engines, food services and housekeeping.

Sarimah and Norshahril (n.d.) conducted a study on obstacles faced by disabled people (hearing impaired) in getting a job. In the study, the researcher suggested several ideas:

1. All employers must have basic facilities for disabled people.

2. Counselling and guidance teachers should give them motivational exercises before they end their schooling so that they will be more motivated.

3. Students with special educational needs must be independent and confident in deciding on their career.

4. Exposure should be given to the families of disabled children in order for them to have a positive outlook in raising their children to have a better future.

Stemming from the needs of these special needs children as expounded by the above studies, this study was carried out to explore the process in consulting job opportunities and marketability of these special needs individuals between special education teacher trainees at the Universiti Kebangsan Malaysia and the parents of students with special educational needs at secondary schools. Through this study the researchers observed the present knowledge of parents in job marketability which involved the skills needed by their children for their future work. 


\section{OBJECTIVE OF THE STUDY}

The purpose of the study was to explore the consultation process for job marketability conducted by special education teacher trainees for students with special educational needs and their families based on the learning outcomes in class. The objective of the study is to explore the knowledge on job marketability among parents of students with special educational needs.

\section{METHODOLOGY}

The study was conducted using qualitative approach with case study design. There were 33 special education teacher trainees of semester 5 from the interpersonal communication, counselling and consultation class involved in this research. The trainees were divided into 11 groups where each group provided consultations to a family of students with special educational needs. The study was done in two phases whereby in the first phase the trainees were exposed with consultation strategies in class for two weeks. The trainees attended a career workshop in increasing their knowledge on suitable jobs at school. Exercises and discussions as part of the consultation were carried out for three hours in order for the trainees to understand the process of consultation which will be carried out for the students of special needs and their parents at school. In this study, 11 families with special needs children determined by purposive sampling was chosen as the respondents of the study. The consultation was carried out for three hours based on the consultation manual prepared by the researchers.

In the second phase, the consultation process was presented by the trainees in a workshop for two days. In the workshop, all the trainees presented their reflections and feelings during the consultation with the families. Their reflections in the workshop were recorded and documented in written report so will be findings of the study. Recordings of the consultation in audio form and video were transferred into verbatim to be main research findings. Both data were analysed using Nvivo in order to create themes related to the objectives of the study.

\section{FINDINGS}

The research findings revealed interesting outcomes in exploring the knowledge on job marketability among parents of the students with special educational needs. In this study, both parents and families admitted that they did not have the necessary 
knowledge on the skills needed by their children in order for them to work as normal children. From 11 families, only four families had such a knowledge about job marketability for their children and seven families admitted do not had the knowledge.

\section{Exploring the Knowledge on Job Marketability among Parents of Students with Special Educational Needs}

In the study, only four families out of 11 families admitted that they had some knowledge on job marketability suited to their children's abilities and skills. One of them chose Giat Mara as a skill training centre for his child.

Actually I knew the fields offered by Giat Mara...towards skills... more on skills...

(Family 1)

All four families chose skill training for their children so that their children could have some level of job marketability. Such parents were aware that giving their children proper skill trainings could help them in getting a job in the future. There were even parents who had a close relationship with the special education teachers to the extent that the special students were able to gain knowledge about the skills needed to train with the corporate sector.

I am looking for extra information to send Nisa to community centres like interesting school programme that she told us...every Thursday the special students will go to Tesco to arrange items on the racks, which the skill can be related to the special students...

(Family 1)

In the study, there were parents who always relied on the special education teachers to convey information that were related to the training and skills which could provide job opportunities for their children. Thus, teachers who are involved with special education with the knowledge in managing students for job marketability are important since such knowledge can reduce the emotional burden of the parents.

I like to seek the teacher if he wants any information...

(Family 3) 
Meanwhile, the seven families in the study admitted that they did not have any knowledge on job marketability. The parents only relied on the teachers and school because they did not have any clue on how to get the required information to plan their children's job marketability. They did not have a clear vision on what to do and expected the school and the government to help them by giving information and guidance.

I don't have any information and we don't know how to get info. Any information that we get...is from school but the teachers did not give much info...

(Family 9)

Low economic status among the parents resulted in the lack of knowledge on job marketability. Both parents were too busy with work to support their family, particularly the father, that they did not have time to look for information on job marketability to plan for their children's future.

I do not have much time with kids. The father works from morning till night, then me works from evening till morning...the father is a lorry driver...so time...

(Family 11)

Throughout the study, only four families had the knowledge on job marketability while the remaining seven families did not have such a knowledge. Those with the knowledge were able to guide and provide motivation and support by going to school and training centres. Moreover, they always cooperated with teachers and schools in skill-based activities organised by them.

\section{DISCUSSION}

Knowledge on job marketability can help the parents plan their children's needs for the job market. According to Klassen (2007) students with learning disability are able to plan and make decision in their career if continuous social skill and job trainings are given to them. In the study, consultations on job marketability carried out by the teacher trainees to parents managed to give them some insights on job marketability. The information also helped them in playing an active role in choosing the right training center for their special children. Therefore, by having the knowledge of marketability, the parents were able to plan and act accordingly in sending their special children for training at suitable institutions (Akin-Little et al., 2004). 
Career information that are well suited to the students' abilities and capabilities can be channelled properly through the teacher trainees for students with special educational needs and their families while in school. At school, special education teachers are the closest figures with their parents and families. Parents and families have high expectations on special education teachers to give them the support required for their special children to join the job market after they finish secondary school. Hence, if special education teachers can provide job-oriented information in the field of appropriate trainings that have high prospects in the job market in Malaysia, this will improve the well-being of special education students (Duckett et al., 2010; Klassen, 2007). For special education students from families who have no information or lack of information can also be helped to enable them to support their child to enter the job market after they finish secondary school. As such, interoperability consultancy interventions can help special education students' parents plan for more effective preparation to enable them to get into the world of better work. This is because it is not easy for special education students to adapt to the workplace environment and to communicate well when in the workplace (Aliza, 2014).

\section{CONCLUSION}

Providing a wide range of job opportunities in the market for people with disabilities especially amongst special education students in Malaysia should be given serious attention by various government and private parties. Involvement of various government agencies, private sector, NGOs and local communities is critical in assisting people with disabilities to be self-reliant. The strategy to maximise collaborative consultations between special education teachers and parents will help students with disabilities to plan their career path when they graduate from the secondary school or even higher levels of education training. Information, knowledge and expertise among special education teachers with the willingness and commitment of parents who have the talent knowledge or potential of their children can guide and develop special education students who have the value of marketability in various areas of work according to their ability. If the consultancy of job-workability between parents and education teachers can be carried out on an ongoing basis, this can relate to the country's desire that this special education children can meaningfully contribute to the nation's prosperity. As a result, families with these special needs children can enjoy the well-being of the psychological, psychosocial and socioeconomic realisation. 


\section{REFERENCES}

Aizan Sofia Amin, Jamiah Manap, \& Noremy Md Akhir. (2016). Peranan keluarga dalam kehidupan kanak-kanak kurang upaya Malaysia. Akademika, 86(1), 21-30.

Akin-Little, K. A., Little, S. G., \& Delligatti, N. (2004). A preventative model of school consultation: Incorporating perspectives from positive psychology. Psychology in the Schools, 41(1), 155-162. https://doi.org/10.1002/pits.10147

Aliza Alias. (2014). Transition program: The challenges faced by special needs students in gaining work experience. International Education Studies, 7(13), 192-196. https://doi.org/10.5539/ies.v7n13p192

Coyne, I. (2006). Consultation with children in hospital: Children, parents' and nurses' perspectives. Journal of Clinical Nursing, 15, 61-71. https://doi.org/10.1111/ j.1365-2702.2005.01247.x

Duckett, P., Kagan, C., \& Sixsmith, J. (2010). Consultation and participation with children in healthy schools: Choice, conflict and context. American Journal of Community Psychology, 46, 167-178. https://doi.org/10.1007/s10464-010-9327-8

Hammack L. (1994). Consulation knowledge, skills, and attitudes of recently trained school psychologists in Ohio. Unpublished doctoral dissertation, Ohio State University.

Hoskins, W. J., Astramovich, R. L., \& Smith, S. D. (2007). School counseling consultation: A comparison of parent, teacher and conjoint modalities. Guidance \& Counseling, 21(3), 152.

Izzo, M. V., \& Lamb, P. (2003). Developing self-determination through career development activities: Implications for vocational rehabilitation counselors. Journal of Vocational Rehabilitation, 19, 71-78.

Klassen, K. (2007). Career exploration experiences for children with disabilities. Unpublished Masters thesis, University of Manitoba.

Lau, P. L., Ahmad Shamsuri Muhamad, \& Chew, F. P. (2011). Peranan kaunselor dan perkhidmatan kaunseling kerjaya bagi orang kurang upaya. Atikan, 1(2), 233-246.

Ministry of Women, Family and Community Development. (2006). Executive Summary Report: "Exploring the Issues of PwIDs in Adulthood: A Report of the Situation of People with Intellectual Disabilities in Penang”. Retrieved from http://www. asiacommunityservice.org/Publications/Executive Summary english.pdf

Perera-Diltz, D. M., Moe, J. L., \& Mason, K. L. (2011). An exploratory study in school counselor consultation. Journal of School Counseling, 9(13), 1-25.

Sarimah Ismail, \& Norshahril Abdul Hamid. (n.d.) Halangan orang kurang upaya (pendengaran) di Malaysia mendapat pekerjaan. Retrieved from http://www. fp.utm.my/ePusatSumber/listseminar/medc2012/pdf/133.pdf

Zainudin Mohd. Isa, Norani Salleh, \& Ramlee Mustapha. (2009). Kurikulum Pendidikan Vokasional Murid Bermasalah Pembelajaran (MP). DP. Jilid 9, Bil. 2/2009. 